\title{
Unsound science? Transatlantic regulatory disputes over GM crops
}

\section{Les Levidow and Susan Carr}

\author{
Centre for Technology Strategy, Open University, Milton Keynes MK7 \\ 6AA, UK \\ Fax: +44-1908-654825/652175Ｅ-mail; L.Levidow@open.ac.uk
}

\begin{abstract}
In the risk debate over genetically modified (GM) crops, Europe's regulatory delays have often been branded as 'political', i.e. not based on science. Yet the US slogan 'sound science' tends to conceal value-laden features of safety claims, their weak scientific basis, their normative framing and their socio-political influences. By contrast a 'precautionary approach' can more readily identify scientific unknowns to be investigated, while acknowledging the agricultural-environmental values which inform risk assessment. These issues underlie transatlantic regulatory disputes over insectprotected Bt maize.
\end{abstract}

In both the USA and Europe, public protest has stimulated risk-assessment research on broader cause-effect pathways, as well as more stringent regulation. For harm to non-target insects, however, new evidence of risk has been disparaged as unsound. It has been criticized on various grounds, which could apply just as well to evidence of safety; thus double standards have served to protect safety claims. And non-target harm is deemed acceptable through unsubstantiated comparisons to agrochemical usage. In these ways, 'sound science' operates as an ideology, pre-empting debate on the framing of scientific uncertainty. The real choice is not between 'science versus politics', but rather between ways of linking them.

Keywords: Sound science; science-based regulation; environmental protection; precautionary principle; risk; biotechnology; genetically modified (GM) crops; Bt maize/corn.

Reference to this paper should be made as follows: Levidow, L. and Carr, S. (2000) 'Unsound science? Transatlantic regulatory disputes over GM crops', Int. J. Biotechnology, Vol. 2, Nos. 1/2/3, pp.257-273.

Biographical notes: Les Levidow is a Research Fellow at the Open University, where he has been researching the safety regulation and innovation of agricultural biotechnology since 1989. He has been Managing Editor of the journal Science as Culture since its interception, as well as co-editor of several books.

Susan Carr is a Senior Lecturer in Systems at the Open University, where she writes for courses on environmental, agricultural and managerial issues, in both developing and developed world contexts. Her current research includes the role of non-governmental organizations in global environmental policy, as well as European biotechnology regulations. 


\section{Introduction: unsound science?}

The proper link between regulatory policy and science has been controversial in many sectors. Regulators request scientific evidence on criteria that may differ across countries and change over time. This essay focuses on differences relevant to transatlantic tradee disputes over agricultural biotechnology. Genetically modified (GM) products have become a test case for the counterposed slogans of 'sound science' versus 'the precautionary principle'.

For GM food safety, 'substantial equivalence' has been a focus of recent debate as a scientific-political concept, but with little reference to its practical interpretation. In assessing GM food safety, the USA and the European Union use the concept in different ways. The US Food and Drug Administration has generally accepted company claims that GM foods have 'substantial equivalence' (with a non-GM counterpart) and so warrant no safety testing. Such claims cannot be independently verified, partly because the company data are not publicly available. EU regulatory procedures have imposed relatively more stringent criteria [1,2]. Despite this difference, the EU authorities have not rejected any products as unsafe, though they have requested more data on products whose antibiotic-resistance marker genes may be intact.

GM crops have been more contentious than GM food in European regulatory procedures. Such products have obtained commercial approval more readily in the USA than in Europe, where similar products have faced long regulatory delays. By 1999 one third of the US maize crop was genetically modified, which was not normally segregated from the non-GM crop; the various harvests became mixed, regardless of whether the $\mathrm{GM}$ varieties had EU approval. Consequently, some mixtures have been blocked from entering Europe. Even more types of GM crops lack EU authorization for cultivation (than for food or feed purposes). The regulatory delays have led the USA to threaten legal action at the World Trade Organization against the EU for imposing 'non-tariff trade barriers', on grounds that these lack any scientific basis.

Under the WTO agreement, the grounds for an import ban remain open to interpretation. Restrictive trade measures can be justified if they are necessary to protect human, animal or plant life or health (Article XX, b) or for 'the conservation of exhaustible natural resources' (Article XX, g). These measures should not constitute 'a means of arbitrary or unjustifiable discrimination among countries where the same conditions apply, or a disguised restriction on international trade' [3, p.38].

According to the Sanitary \& Phyto-Sanitary (SPS) provisions, Article 5(7), restrictive trade measures can be justified on a provisional basis: "In cases where relevant scientific evidence is insufficient, a Member may provisionally adopt sanitary or phytosanitary measures on the basis of available pertinent information", while seeking "additional information necessary for a more objective assessment of risk within a reasonable period of time". However, these measures should not constitute "a means of arbitrary or unjustifiable discrimination among countries where the same conditions apply, or a disguised restriction on international trade" [3].

Central to this dispute is whether the burden of evidence is assigned to those who claim risk - or safety. When the case of hormone-treated beef entered the WTO disputes settlement procedure, the EU was assigned a stringent burden of evidence to demonstrate risk. According to some critics, international trade rules "increasingly assume that new products are safe until proven otherwise", implicitly following the US policy of "sound science' [4]. 
For the Millennium Round negotiations on GM crops, the US government proposed "disciplines to ensure that trade in products of agricultural biotechnology is based on transparent, predictable and timely processes" - perhaps euphemisms for rapid approval unless risk can be readily proven. The US framework for GMOs has been officially justified as 'risk-based regulation' or 'science-based regulation'. The extent of regulatory burdens, as well as the pace of commercial approval, have been justified by 'sound science'.

Although such phrases are heard in Europe too, they coexist with 'the precautionary principle', which is officially linked to GMO regulation [5, p.8]. That principle has been widely invoked as grounds for delaying approval of many GM crops. Regulators have cited new evidence of risk (or uncertainty), or have requested more evidence of safety.

According to some proponents of safety claims, precautionary regulation is misguided on several grounds: that it imposes an unrealistic burden of proof for safety; that it discriminates against GM crops; and that it ignores the lower risk of GM products relative to the agrochemical risks of cultivating their non-GM counterparts. In their view, precautionary delays are a proxy for 'non-risk' issues, e.g. about trade policy or intensive agriculture; beneficial products have been sacrificed to accommodate public protest and irrational fears. They attribute European regulatory delays to political rather than scientific reasons.

That diagnosis begs some questions: How can sound science be distinguished from unsound science? [6] When research provides new evidence of risk (or of uncertainty), does the earlier science become unsound, retrospectively? Alternatively, is the new evidence to be discredited as unsound? Moreover, can there be an apolitical way of basing decisions upon science?

Starting from such questions, this essay analyses how the 'sound science' and 'precautionary' slogans frame the relevant cause-effect uncertainties for risk regulation. It starts with theoretical perspectives on uncertainty, risk-framing and precaution. Then insect-protected $\mathrm{Bt}$ maize provides a case study for transatlantic comparison [7]. The conclusion discusses the role of the two slogans. (For more detail and references on the case study, see [8]).

\section{Theoretical perspectives: framing risk}

Many technological-environmental controversies revolve around scientific uncertainty, featuring arguments such as 'more research is needed'. This response may be used as a political strategy to delay contentious decisions, to accommodate disagreements, and/or to gain resources for gathering more scientific information. In practice, additional research often leads to further controversy over how to interpret the experimental results, partly because the research is grounded within a particular model of the relevant uncertainty. Although funded in order to guide policy, the scientific research itself is often 'driven by policy directives' and their epistemic criteria [9].

Although scientific uncertainty is normal, its rhetorical use is socially contingent. Moreover, according to Wynne [10], scientific uncertainties cannot be properly described as objective shortfalls of knowledge. Rather, the perceived uncertainty is a subjective function of complex social and cultural factors: "Scientific uncertainty can be enlarged by social uncertainties in the context of practical interpretation, and it can be reduced by 
opposite social forces". These factors go beyond different interpretations of the available data. As a result of debate over cause-effect models of harm, "the body of knowledge itself may change'; research may set new priorities for 'what is defined scientifically as problematic or not" $[10$, p.120, 125).

In risk assessment, moreover, technical evidence depends upon worldviews about nature and society. This feature has been theorized as a 'framing', which underlies all risk knowledge. In seeking and organizing more facts about risk, we make socio-political choices, e.g. about what potential harms to prevent and about what opportunities to forego. "We can hardly order, rearrange, or usefully supplement our knowledge about risk without incorporating these issues into a clear, framing vision of the social and natural order that we wish to live in" [11, p.129]. Indeed, predictive uncertainty may be framed by socio-political models of control over nature.

Such perspectives can illuminate the meaning of the precautionary principle. According to the 1990 Bergen Ministerial Declaration,

\begin{abstract}
"In order to achieve sustainable development, policies must be based on the precautionary principle. Environmental measures must anticipate, prevent and attack the causes of environmental degradation. Where there are threats of serious or irreversible damage, lack of full scientific certainty should not be used as a reason for postponing measures to prevent environmental degradation" [12, p.245].
\end{abstract}

When the precautionary principle was adopted by the 1992 Rio UNCED conference, 'measures' was changed to 'cost-effective measures', with the extra proviso that 'no unfair or unjustified barriers for trade' should be imposed by national governments (cited in [13]).

Those precautionary criteria can be ambiguous or even inconsistent, taken together. 'Cost-effective' implies adequate prior knowledge about the potential harm to be prevented. Logically speaking, 'full scientific certainty' is never possible anyway. The precautionary principle remains open to interpretation; its practical meaning depends on the types of uncertainty which are emphasized, investigated and managed. It can be seen as "an expression of environmental value, phrased in the rhetoric of science" [14, pp.120-23].

Given those ambiguities, scientific superiority is often claimed for conventional risk assessment.
"However, where the characterization of 'science' is extended to include an acknowledgement of the multidimensional scope of risk, the incommensurability of different classes and aspects of risk, and the formal conditions of strict uncertainty and ignorance (rather than just the narrow formal concept of risk), then it is the 'precautionary' approach which is revealed as being the more 'scientific' " [15, p.38].

A precautionary approach is not less 'objective' but more explicitly value-laden, as regards the acknowledgement and study of scientific unknowns. What do those differences mean for regulating GM crops?

\title{
3 Insect-protected crops: risk issues
}

Since the 1980s GMOs have been promoted as 'environmentally-friendly products', while critics have disputed such claims [16]. According to proponents, GM crops offer a 
natural extension of traditional breeding, precise genetic changes, and safe remedies for the problems caused by intensive agriculture. For example, 'in-built genetic information' helps GM crops to protect themselves from pests and disease, thus reducing dependence upon agrochemicals ([17]. cf. [18]).

According to critics, however, GM crops impose unknown ecological risks, reduce the biodiversity of plant cultivars, direct R\&D according to commercial criteria, and promote the further industrialization of agriculture. Critics warn that such products will aggravate the hazards of intensive agriculture - e.g. by extending dependence upon agrochemical or single-gene solutions, by accelerating resistance to plant pests, and thus by establishing a 'genetic treadmill' scenario, by analogy to insects which acquired resistance to chemical pesticides. In their view, sustainability must mean reorganizing agricultural systems to avoid the monocultural conditions which attract pests and disease.

Among the earliest GM products were 'insect-protected' crops, containing a gene from the bacterium Bacillus thuringiensis (Bt) that codes for a protein that is toxic to some insects - e.g. the European corn borer. When the protein is ingested by the larvae of those species, their digestive enzymes cause it to bind to specific receptors on the intestinal lining; the insects soon stop feeding and may die. By producing the toxin continuously, the plant offers long-term protection.

Emphasizing that persistence, critics highlighted two types of risk. The widespread use of Bt maize could generate selection pressure for insects that are resistant to the toxin, thus jeopardizing the product benefits and perhaps undermining the efficacy of naturally occurring $\mathrm{Bt}$ for organic farming as well. And the insecticidal gene could harm non-target insects, including those that prey on the target pest.

There has been much debate on ways to minimize or mitigate the selection pressure for resistant insects. Some biotechnology companies are attempting to develop new $\mathrm{Bt}$ toxins faster than insects can acquire resistance to them. As one company official proclaimed in 1991, "We have many bullets in the gun which we call Bt". Even if insect resistance were to develop in five years, the company would still receive an adequate return on its investment.

At the same time, companies have been devising strategies for insect resistance management (IRM), notably the 'high-dose/refuge' strategy. The crop is designed to produce enough toxin to kill nearly all resistant insects; meanwhile a nearby area of nonBt plants allows some susceptible insects to survive and breed with resistant ones, thus diluting the resistance gene in subsequent generations. This strategy assumes that $\mathrm{Bt}$ resistance is a semi-recessive trait, i.e. that heterozygously-resistant individuals will be killed by a high dose.

In regulating $\mathrm{Bt}$ maize, the USA and EU have devised criteria which both overlap and differ. The differences arise partly in response to different cultural meanings of agriculture. US farms are seen as analogous to factories, sharply demarcated from wilderness and nature conservation areas. Although European agriculture also uses chemical-intensive methods, farmland there is widely regarded as an integral part of the environment - by providing an aesthetic landscape, wildlife habitat and local heritage. 


\section{USA: Bt as 'public good'}

The US regulatory system for GMOs was shaped in the 1990s around the slogan, 'riskbased regulation'. This assigned Federal agencies a strong burden of evidence to demonstrate risk even before regulating GMOs at all. Like the proponents of agricultural biotechnology, regulators too adopted the 'sound science' slogan, partly to defend their new role from anti-regulatory pressures, especially those directed at the Environmental Protection Agency [19]. In practice 'sound science' involves non-scientific criteria, which can be analysed in agency rule-making and product decisions [20].

Initially the EPA planned to regulate GM microbial pesticides, though not necessarily plant pesticides. Environmental NGOs successfully pressured the EPA to regulate such toxins, and even insect resistance, by extending its authority under the Federal Insecticide, Fungicide, and Rodenticide Act. FIFRA requires the EPA to balance the risks against the benefits when approving pest-control agents.

EPA officials declared that insect-protected crops would significantly reduce the risks associated with the use of synthetic pesticides. However, the prospect of insect resistance undermined the longevity of the presumed benefits. The agency eventually accepted the responsibility for preserving the efficacy of Bt as 'a public good' through efforts to minimize insect resistance.

In 1995 the EPA approved the GM toxin in three different Bt crops, on successively more stringent terms. For the first, a potato developed by Monsanto, no specific obligations were imposed on the company [21]. In response, environmental NGOs and organic farming groups issued an 'action alert'. The EPA then received several hundred letters criticizing it for prematurely allowing the commercialization of the Bt potato and thus potentially undermining the effectiveness of microbial Bt.

Under such pressures, the agency adopted a more stringent approach in subsequent applications for commercializing Bt maize. EPA officials mentioned at least two grounds for this shift. The corn earworm is also the cotton bollworm, so resistance in cornfields could affect cotton too. Also the EPA's conditions would provide credibility for the companies' efforts at product stewardship (OPP-EPA interview, 23.10.95).

When evaluating Bt corn products from Ciba-Geigy and Mycogen, the EPA did not expect these crops to dominate the corn market in the early years, when there would be natural non-Bt refuges between fields; therefore 'market-driven unstructured refuges' would be adequate to delay resistance. But the EPA required some measures for Insect Resistance Management (IRM), in order to preserve the efficacy of Bt sprays as well as that of the Bt crop itself. The IRM plans required "close monitoring of the plant pesticide to determine if resistance is developing," i.e., if there were any surviving pests [22].

\subsection{IRM tightened}

According to environmentalist critics, EPA was simply assuming that Bt crops would reduce agrochemical usage. They criticized the agency for optimistically accepting the high-dose/refuge strategy, while ultimately looking to a genetic treadmill solution. To highlight the need for caution, environmental NGOs publicized expert arguments about the limitations of IRM strategies (e.g. [23]). They were joined by organic farmers in strategy discussions with regulators, academic scientists and companies.

Mishaps with Bt crops soon reinforced doubts about their long-term benefits. In July 1996, Monsanto's Bt cotton succumbed to bollworm in some southern states. The IRM 
plan had presumed that a high dose would kill virtually all the target pests, so critics questioned whether it was adequate to delay resistance. A leading entomologist argued that bollworm is less sensitive to the Bt toxin than are other pests, "so it is misleading to use this cotton in a high-dose/refuge approach." The EPA soon restricted the cultivation of Bt maize in the South, in order to prevent resistance in the corn earworm [24].

The adequacy of IRM strategies became more contentious through further scientific evidence and debate. Bt resistance may not always be a semi-recessive trait; if dominant, it could spread more rapidly in target insects (cited in [24]). Some insect pests were found to have single-gene resistances to four different types of Bt [25]. Citing this crossresistance, experts questioned the contingency plan of substituting alternative Bt genes if insects developed resistance to the initial one.

If a pest already has high background levels of resistance genes, then considerable resistance may develop within three to four years, despite the prevalent refugia strategy [26,27]. According to other scientists, the rate of resistance-development depends less upon the initial frequency than upon the survival rate of heterozygously-resistant insects [28]. That factor makes it more important to ensure the efficacy of the high dose/refuge strategy.

Consequently, EPA advisors recommended tightening the IRM strategies. These arguments were publicized by NGOs ([29]; cited in [30]). In May 1998, the EPA's Scientific Advisory Panel further recommended stricter requirements for refuges.

Heeding that advice, EPA tightened its controls in granting two further authorizations for Bt maize; it mandated that non-Bt refuges cover $20-30 \%$ of the cultivated area or $40 \%$ if sprayed with insecticide. In setting these requirements, the agency again cited the need to preserve the efficacy of Bt sprays as well as that of the Bt crop itself ([31,32]; cf. [33]). Soon the larger refuges were being promoted by some companies, though there were differences among the four competing to sell Bt maize.

In 1998 all four participated in an expert panel that devised a 'science-based framework' for managing insect resistance to Bt [34]. Their report specified refuge sizes that in some cases were larger than those in previously mandated plans. Farmers would also be required to sign contracts undertaking to follow the guidelines. These arrangements were intended to avoid several potential problems: differences among the four companies, confusion among farmers, and more stringent EPA requirements. The guidelines were endorsed by the National Corn Growers' Association.

The guidelines for IRM measures were widely promoted as 'science-based'. However, their acceptance had a reverse logic: in practice, 'sound science' was defined by the prevalent industry view, which became more precautionary in responding to public and regulatory pressures. Indeed, for GMO regulation in general, the EPA's expert authority has depended upon industry consent and inter-agency agreements [19].

\subsection{Monarch studies disputed}

For evaluating harm to non-target insects, the original safety claims prevailed until new research undermined the official 'sound science' in 1999. Initially the USA had little debate on this risk, mainly because environmental NGOs had decided to prioritize the IRM issue. Eventually a Cornell University laboratory study indicated that Monarch butterfly larvae were harmed by feeding on milkweed which had been dusted with GM Bt maize pollen [35]; official risk assessments had ignored this cause-effect pathway. The 
EPA was soon petitioned to require farmers to plant buffer zones around Bt maize, mainly in order to protect the Monarch butterfly [36].

In response, many scientists criticized the Cornell experimental design and its findings. According to the chief regulatory officer at Novartis, force-feeding Bt to larvae does not represent reality in the field, where insects might avoid Bt-coated leaves in favour of other leaves (cited in [37]). According to a company statement, Novartis Seeds was evaluating in-field research protocols designed to provide 'real-world answers' to the theoretical issues raised by the Cornell study. According to the chief scientist for $\mathrm{Bt}$ maize at Monsanto, $\mathrm{Bt}$ toxin in pollen is below 0.1 parts per million, a level too low to kill cornborers, so Monarch larvae should not be affected in the field (cited in [38]). As a journalist remarked, "Some want to know why intensive studies weren't already done with a product of major potential ecological significance" [38].

These arguments drew attention to a field study previously done at Iowa State University. Leaf samples taken from within and at the edge of the cornfield were used to assess mortality of first-instar monarch larvae exposed to Bt or non-Bt corn pollen. "Within 48 hours, there was 19\% mortality in the Bt corn pollen treatment, as compared to $0 \%$ on non-Bt corn pollen exposed plants and $3 \%$ in the no-pollen controls" [39].

Although the Iowa researchers studied 'real-world' conditions, their results drew sceptical interpretations. For example, "Pollen levels were highest within the field (where Monarchs are scarce), but even there Monarch mortality was only 16\%", argued two entomologists [40]. An industry spokesperson emphasized that the Monarch butterfly is not an endangered species, thus implying that considerable harm would be acceptable. Thus the importance of predicting harm depends upon its acceptability - not a purely scientific matter.

At a one-day symposium on this issue, industry-funded studies reported evidence that Monarch larvae would have little exposure to Bt pollen on milkweed leaves, especially outside maize fields. At the same time, several participants emphasized that scientists know little about the 'real-world' interaction between butterfly larvae, milkweed and maize pollen [41].

A frequent argument is that Bt maize causes less harm than chemical insecticides. This rests upon two dubious assumptions: that maize is otherwise sprayed with insecticides, for which the need is eliminated by Bt maize [42-45]. However, only $20 \%$ of US maize fields is sprayed with such chemicals, partly because the treatments are not very effective. So that fraction should be 'realistically' compared with the $30 \%$ of maize fields now expressing the Bt toxin, and with perhaps half of all maize crops eventually doing so - i.e., far more widespread than agrochemical usage. By citing chemicalintensive methods as an environmental standard, proponents of Bt maize extrapolate such a model to all agricultural fields.

Under environmentalist pressure to protect Monarch butterfly larvae, the EPA announced two extra measures for the year 2000 growing season. On a voluntary basis, "we suggest farmers locate refugia in such a manner as to serve to protect potentially vulnerable non-target insects", since refugia areas can serve as buffer zones between the corn field and the habitat of non-target insects (cf. [36]). On a mandatory basis, registrants must submit protocols outlining their strategies for collecting data on the various factors relevant to non-target harm [46]. Thus a clear scientific basis is the goal, not the prerequisite, for more stringent controls. 


\section{Europe: multi-risk precaution}

For regulating GMOs in the European Community, policy statements have included both precautionary and 'risk-based' language. The Deliberate Release Directive 90/220 was intended to provide "a high level of protection for the environment and human health", as well as to 'establish harmonized procedures and criteria' for Europe-wide market approval of GM products [47]. Although the directive was called 'preventive', the term implicitly meant 'precautionary'. Later its rationale was elaborated: GMOs “could upset the delicate balance existing in nature or even have evolutionary impacts". Official documents still described the Directive as 'preventive', even after adopting 'the precautionary approach' for pollution control [48, p.24, 60]. On the other hand, the European Commission also sought to ensure that 'advances in scientific knowledge are constantly taken into account and that regulatory control is based on potential risks' of GMOs [49, pp.100-103].

Citing this 'risk-based' language, regulators defined the relevant uncertainties narrowly enough to be readily testable before approving products. In 1996-97 some GM crops were granted EU-wide commercial approval, despite criticisms of the official risk assessment for failing to evaluate some potential effects. According to proponents of approval, these effects did not require scientific evaluation because they would be 'agricultural problems', rather than any 'adverse effects' relevant to the Directive [50,51].

Meanwhile, partly in response to the BSE crisis, the EU's scientific committees were reorganized in mid-1997. Prospective members were invited to submit applications (rather than be nominated by member states), to declare any relevant material interests, and to enter a selection procedure. In this way, the European Commission sought to keep scientific advice independent from politics, and thus to separate 'risk assessment' from 'risk management', i.e. product approvals. Unofficially, some committee members saw their role as protecting risk assessment from political influences which led EU member states to delay product approvals.

\subsection{National controls imposed}

In 1994 Ciba-Geigy submitted a marketing application for a Bt maize to the French authorities, thereby making France the rapporteur for the EU-wide procedure. Member states raised questions not only about the Bt gene but also about the two 'markers' used, one of which conferred tolerance to a herbicide and to the antibiotic ampicillin; critics warned that the latter could spread from unprocessed food (or animal feed) to gut pathogens, thus undermining the clinical efficacy of the antibiotic.

Despite objections from most countries, the European Commission approved the application. In doing so, it accepted the French authorities' judgment that the emergence of insect resistance "cannot be considered an adverse environmental effect, as existing agricultural means of controlling such resistant species of insects will still be available" [52]. Insect resistance was deemed an agricultural problem, not an environmental threat. In effect, the biopesticide Bt would be treated as dispensible, ultimately replaceable by chemical insecticides.

In 1996-97 the first shipments of GM maize and soyabeans arrived in Europe from North America. These imports provided a focus for campaign groups, which generated a debate on environmental risks of all GM crops. By 1998, there was an intense public 
controversy in France. Numerous scientists, environmental NGOs, and the peasants' confederation were demanding a complete moratorium on all GM crops. Innovation research on herbicide-tolerant oilseed rape was abandoned by the government-funded Institut National de la Recherche Agronomique. According to some staff members, 'extreme caution is necessary in the face of a major innovation which has, as yet, unknown effects' [53].

Consequently, after gaining EU-wide approval, Ciba-Geigy's Bt maize encountered further delays under the National List procedure, which requires registration for any new crop variety. In February 1998 the French government finally registered Ciba-Geigy's maize (by now merged into Novartis). Unusually, the registration was granted only for three years and required monitoring for various environmental effects, including the efficacy of the Bt toxin, insects' resistance to it, harm to non-target insects, and spread of the ampicillin-resistance gene. In its National List procedure, Spain imposed similar requirements on the $\mathrm{Bt}$ maize, along with a general monitoring requirement for all GM crops listed in the future.

As regulatory criteria became more stringent in practice, the EU-level Scientific Committee on Plants was asked to evaluate the IRM plans. The committee concluded that they would be "adequate to delay resistance," while implying that such an effect would be an agricultural problem rather than an "adverse effect" under Directive 90/220 [54]. Thus the official expertise reaffirmed the original acceptance of the genetic-pesticide treadmill.

Parallel research was needed to inform the IRM strategies. Meaningful laboratory testing depends on knowing the previous level of Bt susceptibility in the insect population, so Novartis commissioned entomologists at the University of Milan to establish a baseline. The refuge design depends on assumptions about the distance travelled by insects to feed and breed, so biotechnology companies also contracted with entomologists to study these behaviours. To create refuges that would minimize selection pressure, Novartis originally planned to follow the early EPA guidelines but later adopted that agency's more stringent ones.

Commercial cultivation in France was still criticized by environmental NGOs. Nevertheless some representatives accepted a government invitation to participate in a biovigilance committee, to evaluate the monitoring methods for all risks. When reconstituting its overall advisory committee on GM products, the government likewise included critics [55]. In these ways, public concerns could be accommodated by more stringent criteria for evidence of safety.

\subsection{Lacewing studies disputed}

Early in the European regulatory procedure, potential harm to non-target insects became an issue, especially as regards what inferences could be drawn from available knowledge. Some safety arguments cited the absence of any harm from foliar sprays containing $\mathrm{Bt}$ microbes, which had been widely used in the USA. With such sprays, the microbial form has a low persistence on the leaf, and the crystalline Bt toxin is converted into its truncated active form in the pest's gut. By contrast, most Bt plants express the toxin continuously and in an active form, which therefore could affect insects differently than a foliar Bt spray would do.

When requesting EU approval, company applications cited field surveys of potential harm to beneficial insects; no fewer beneficial insects were found in Bt-crop fields than 
in non-Bt fields. Companies also cited laboratory tests of microbial Bt on several insect species, which had showed no evidence of harm (e.g. [56, C-10; [57, pp.45-47]). Critics proposed that the applicant redo the tests with more beneficial insect species, and using Bt derived from the Bt plant. However, enormous quantities would be needed in order to extract a high dose (according to Monsanto, interview, 24.11.97). Subsequent tests used microbe-derived $\mathrm{Bt}$ of the same type which is inserted into crops (e.g. [58]). Other tests used pollen from Bt plants, with the conclusion that the pollen "does not have acute toxin effects on three prominent predators found in corn" [59].

Those laboratory tests used carnivorous insects further along the food chain, e.g. the lacewing, which is known to prey specially on aphids in maize fields. After lacewing were fed moth eggs coated with a Bt concentration for seven days, the larvae showed no adverse effects ([60]; cited in [57, p.46]). However, lacewing in the field normally suck out the contents of eggs, rather than ingest the eggshells. Also the seven-day test contrasts with a 30-day generation time in the field. Despite the unrealistic experimental conditions, the test method was not challenged.

An alternative test method is a tri-trophic study, i.e. involving the plant, a pest and a predator species. In a Swiss study, lacewing larvae ate cornborers which had been fed Bt or non-Bt leaves; the former larvae had a lower survival rate. Similar results were obtained when lacewing were tested on alternative prey, so the effect was not specific to the cornborer.

That alternative test was done partly because lacewing larvae could not survive in agricultural fields by feeding only on prey which is eradicated by the Bt crop, as the researchers acknowledged. According to their analysis, the reduced fitness was directly associated with the Bt toxin, while the prolonged development time was caused by both the Bt exposure and a nutritional deficiency from eating sick prey. If predators were harmed in Bt maize fields, they argued, then farmers would lose a useful means of controlling Bt-resistant insects [61,62].

There ensued further debate over the appropriate methods for testing cause-effect scenarios along the insect food chain. The Swiss experimental design was criticized as 'unrealistic', for example, because lacewing normally eat aphids rather than cornborers. However, aphids feed on the phloem in maize stems, where Bt expression was not reliably known; consequently, Bt-fed aphids would not necessarily provide a more realistic test than other prey.

Double standards were applied when evaluating test methods. At least initially, few regulators questioned whether microbial Bt provides a 'realistic' test of non-target harm from $\mathrm{Bt}$ crops. When that method came under criticism, regulators did not question the adequacy of the eggshell-coat method or a seven-day exposure period.

Double standards were also applied when evaluating mortality rates. The EU-level Scientific Committee on Plants raised methodological doubts about the Swiss study, especially the high mortality of the control insects (chairman of SCP subcommittee on environmental aspects, interview, 17.06.98). However, control insects have had even higher mortality rates in other laboratory studies $[63,64]$ In one study, moreover, the Btexposed insects had $15 \%$ higher mortality than the controls, yet the researchers reported 'no significant difference', thus implying evidence of safety [64]. Neither their interpretation nor their experimental method was challenged. Thus a study convenient for safety claims escaped scrutiny, even though it warranted even more strongly the criticisms which were directed at the Swiss study. 
Alongside its methodological doubts about the new evidence of risk, the EU committee devised a normative judgement. Initially the SCP had stated that 'no risk is identified to non-target herbivores', when assessing Monsanto's Bt maize [54]. After seeing the Swiss study, the committee assessed Pioneer's Bt maize: it stated that any harm to non-target arthropod insects would be less than the present harm from chemical insecticides [64]. In other words, the committee accepted the present effects of chemicalintensive agricultural methods as the normative baseline for the potential effects of GM crops - even though not all maize is sprayed with chemical insecticides. Thus its argument presumed a specific vision of future agriculture.

There ensued further debate over the predictability and acceptability of non-target harm. Such arguments were intensified by the Cornell study [35]. In response, the European Commission delayed approval of a Bt maize from Pioneer Hi-Bred in mid1999; no additional GM crops were granted approval (at least by early 2000). While accommodating political pressures, this delay could cite scientific evidence which was no less 'realistic' than the earlier 'sound science'.

\section{Conclusion: ‘sound science’ as ideology}

The regulatory role of science depends upon various socio-political influences. Risk regulation makes judgements about what 'environment' must be protected, what uncertainties matter for risk assessment, what research is needed to clarify them, and what counts as meaningful evidence. In practice the criteria are framed by regulatory institutions, official expertise, policy language, agricultural models and assumptions about a desirable society (cf. [11]). For GM crops, the 'sound science' slogan has tended to restrict and conceal such political judgements, while 'the precautionary principle' has tended to open them up.

In early decisions to approve $\mathrm{Bt}$ maize, the US and EU procedures framed the risk issues within an intensive agricultural model. A 'genetic-pesticide treadmill' was accepted as if Bt were dispensible, replaceable by chemical pesticides. Non-target harm was deemed implausible. Superficial laboratory tests were accepted as evidence of safety (though more rigorous evidence was requested by some regulators).

These framings had transatlantic similarities. In both the US and EU procedures:

- Intensive agricultural methods and their familiar effects were accepted as a normative baseline for evaluating potential harm from GM crops.

- Cause-effect uncertainties were defined in a way amenable to convenient testing, so that present scientific knowledge could be deemed adequate, while more complex pathways were downplayed or ignored.

- Given some evidence of safety, the burden shifted to those who claimed risks.

Public protest led to a change in this initial framing, though with some transatlantic differences. After US protest campaigns turned insect resistance into a risk issue, regulators acted upon and solicited new scientific evidence about insect-resistance pathways. After GM crops overall became contentious in Europe, its precautionary approach was reinterpreted; national regulators there too imposed greater controls for various risks, including non-target harm. 
The protest stimulated more stringent norms of acceptable effects, as well as further scientific research on cause-effect uncertainties which were previously neglected. In such ways, the risk debate stimulated new bodies of knowledge, rather than simply shifting the burden of evidence within existing knowledge (cf. [10]. These changes offered some opportunity for public participation, e.g. in evaluating the environmental monitoring methods.

Initially risk regulation was expected to judge whether or not a GM crop could be safely used in ways similar to its non-GM counterpart. Instead market-stage precautions have been devised in both the USA and Europe. They involve dynamic links among four elements: cultivation protocols, field monitoring, related ecological research, and causeeffect ecological models [66].

These dynamic links are unstable, especially because research findings can undermine the safety assumptions behind cultivation protocols. For example, new research has undermined optimistic cause-effect models of Bt resistance mechanisms and of available alternative genes. This new knowledge stimulated and informed more stringent protocols for Bt Insect Resistance Management.

For potential harm to non-target insects, however, new evidence of risk has been disparaged as unsound. Such evidence has been criticized on various grounds - e.g. 'unrealistic' experimental conditions or statistical anomalies - which could apply just as well to evidence of safety. Yet the latter was favourably cited by companies and largely accepted by regulators. Thus double standards have served to protect safety claims. Moreover, some comments have implied that any plausible harm would be acceptable, e.g. by favourably comparing Bt maize to harm from agrochemical usage - as if the comparison needed no evidence and involved purely technical issues.

In sum, the slogan 'sound science' tends to conceal value-laden features of safety claims, their weak scientific basis, their normative framing and their socio-political influences. In these ways, 'sound science' operates as an ideology, pre-empting debate on its framing of cause-effect uncertainties. By contrast 'a precautionary approach' can more readily identify scientific unknowns, while acknowledging the agricultural-environmental values which inform risk assessment [67].

As indicated by this case study, a purely 'science-based' regulation can never be achieved. The choice is not between 'science versus politics', but rather between ways of linking them.

\section{Acknowledgements}

This paper arises mainly from a study, 'Safety regulation of transgenic crops: completing the internal market?', funded by the European Commission, DG XII/E5, Ethical, Legal and Socio-Economic Aspects (ELSA), Biotechnology horizontal programme, contract BIO4-CT97-2215, during 1997-1999. Earlier material came from a study, 'From precautionary to risk-based regulation: the case of GMO releases', during 1995-1996 (ESRC project number L211 25 2032). Helpful editorial comments were received from Helmut Gaugitsch, Angelika Hilbeck, and Calestous Juma. The essay represents only the views of the authors. 


\section{References and Notes}

1 Under the EU Novel Food Regulation, a simplified procedure is available for GM products which have 'substantial equivalence' (EC, [2]). Most applications for GM food have been sent to the UK government, which thereby becomes the rapporteur for the EU-wide approval procedure. UK food regulators accept 'substantial equivalence' only for highly processed products, containing no intact DNA. If a product does not satisfy these criteria, then it must undergo a more cumbersome procedure under the Regulation: "All other ingredients derived from GM crops... should be given a full safety evaluation, as they may not have been subjected to the processing associated with highly refined products...", according to MAFF (Nick Tomlinson, speaking at a conference in January 1998). Moreover, a GM food may qualify for 'substantial equivalence' only if the GM crop undergoes more extensive field testing, e.g. for genetic stability (according to a member of the advisory committee, ACNFP, interview, 11.05.98).

2 EC (1997) Regulation 97/258/EC of 27 January 1997 concerning novel foods and novel food ingredients, Official Journal of the European Communities, L 43, 14 February, pp.1-6.

3 GATT (1994) The Results of the Uruguay Round of Multilateral Trade Negotiations: The Legal Texts, Geneva, GATT Secretariat, web pages http://www.wto.org

4 Scott, A. et al. (1999) 'Precautionary approach to risk assessment', Nature, Vol. 402, p.348.

5 CEC (1999) Amended proposal for a European Parliament and Council Directive amending Directive 90/220/EEC, Brussels: Commission of the European Communities, COM (1999) 139 final, 26 March.

6 The title of this article comes from 'The Archers', a radio soap opera set in rural England. In an episode during the 1996 'mad cow' crisis, one character reads a newspaper report of the Agriculture Minister reassuring the public that British beef is safe, based on 'sound science'. Another character responds, 'Well, he's not going to say that it's based on unsound science, is he?'

7 Transatlantic differences are even greater for GM herbicide-tolerant oilseed rape, for which the USA has had little debate on the risk issues important in Europe. So a comparison of regulatory criteria would be less meaningful for this product.

8 Levidow, L. (1999) 'Regulating Bt maize in the USA and Europe: a scientific-cultural comparison', Environment, Vol. 41, No. 10, pp.10-22.

9 Hellstrom, T. (1996) 'The science-policy dialogue in transformation: model-uncertainty and environmental policy', Science \& Public Policy, Vol. 23, pp.91-97.

10 Wynne, B. (1992) 'Uncertainty and environmental learning: reconceiving science and policy in the preventive paradigm', Global Environmental Change, Vol. 2, No. 2, pp.111-27.

11 Jasanoff, S. (1993) 'Bridging the two cultures of risk analysis', Risk Analysis, Vol. 13, No. 2, pp.123-29.

12 Haigh, N. (1994) 'The introduction of the precautionary principle in the UK', in O'Riordan, T. and Cameron, J. (Eds.) Interpreting the Precautionary Principle, pp.229-51. London, Earthscan.

13 Robinson, N., (Ed.) (1992) Agenda 21 and the UNCED Proceedings, Vol. 1., Convention on Biological Diversity, New York, Oceana Publications, available at http://www.biodiv.org

14 Hunt, J. (1994) 'The social construction of precaution', in O'Riordan, T. and Cameron, J. (Eds.) Interpreting the Precautionary Principle, pp.117-25, London, Earthscan.

15 Stirling, A. (1999) 'On Science and Precaution in the Management of Technological Risk', Sussex, SPRU [based on contributions from Renn, O., Rip, A. and Salo, A.], Final Report for EC Forward Studies Unit.

16 Levidow, L. and Tait, J. (1991) 'The greening of biotechnology: GMOs as environmentfriendly products', Science and Public Policy, Vol. 18, No. 5, pp.271-80; reprinted in Shiva, V. and Moser, I. (Eds.) (1995) Biopolitics: A Feminist and Ecological Reader on Biotechnology, pp.121-38, London, Zed. 
17 Magretta, J. (1997) 'Growth through global sustainability: an interview with Monsanto's CEO, Robert Shapiro', Harvard Business Review, Jan-Feb, pp.79-88.

18 Monsanto (1997) Report on Sustainable Development, St Louis, MO, Monsanto Company.

19 Levidow, L. and Carr, S. (2000) 'Normalizing novelty: regulating biotechnological risk at the US EPA', Risk, Vol. 11, No. 1, forthcoming.

20 From an interview with an EPA officer (18.06.96): Q: "How do you distinguish between sound science and unsound science?" A: "It is the least we can do to use the resources at our disposal. There are ways to ensure that our policy is scientifically based". Q: "Couldn't various policies be based upon the same scientific advice?", A: "Yes. In adopting our policy, we have other considerations, e.g. legal and practical".

21 EPA-OPPTS (1995) Bt CryIA(b) delta-endotoxin and the genetic material necessary for its production in corn: significant new use [event Bt-176, for Ciba/Novartis and Mycogen].

22 EPA-OPPTS (1995) Bt CryIA(c) delta-endotoxin and its controlling sequences as expressed in cotton: conditional unlimited registration [for Monsanto].

23 Gene Exchange (1994-98) semi-annual publication by the Union of Concerned Scientists (formerly by the National Wildlife Foundation).

24 Fox, J. (1996) 'Bt cotton infestations renew resistance concerns', Nature Biotechnology, Vol. 14, pp. 1070

25 Tabashnik, B. (1997) 'One gene in diamondback moth confers resistance to four Bt toxins', PNAS 94, pp.1640-44.

26 Gould et al ((1997) 'Initial frequency of alleles for resistance to Bt toxins in field populations of Heliothis virescens', PNAS 94: p.3519-23.

27 Tabashnik, B. (1997) 'Seeking the root of insect resistance to transgenic plants', PNAS 94, 3488-90.

28 Roush, R. and Shelton, A. (1997) 'Assessing the odds: the emergence of resistance to Bt transgenic plants', Nature Biotechnology, Vol. 15, pp.816-17.

29 UCS (1998) Now or Never? Serious New Plans to Save a Natural Pest Control, Cambridge, MA, Union of Concerned Scientists, www.ucsusa.org, email ucs@ ucsusa.org.

30 Fox, J. (1998) 'UCS says EPA Bts around the bush', Nature Biotechnology, Vol. 16, p.324.

31 EPA-OPPTS (1998) Bt CryIA(b) delta-endotoxin and the genetic material necessary for its production in corn [event Bt-176], for Novartis/Mycogen.

32 EPA-OPPTS (1998) Bt Cry9C protein and the genetic material necessary for its production in corn, for PGS (America).

33 Ostlie, K. et al., (Eds.) (1997) Bt Corn \& European Corn Borer: Long-Term Success Through Resistance Management, North Central Regional Research Project (NCR-602). St Paul, MN, Univ. of Minnesota.

34 ILSI (1999) An Evaluation of IRM in Bt Field Corn: A Science-Based Framework for Risk Assessment and Risk Management, Washington, D.C., International Life Sciences Institute.

35 Losey, J., Rayor, L. and Carter, M. (1999) 'Transgenic pollen harms monarch larvae', Nature, Vol. 399, p.214.

36 EDF (1999) Petition to the EPA [to require the planting of buffer zones]. New York, Environmental Defense Fund, July.

37 Hodsgon, J. (1999) 'Monarch Bt-corn paper questioned', Nature Biotechnology, Vol.17, p.627.

38 Palevitz, B.A. (1999) 'Bt or not Bt: transgenic corn vs. Monarch butterflies,' The Scientist, Vol. 13, No. 12, p.1\& p.6.

39 Hansen, L. and Obrycki, J. (1999) 'Non-target effects of Bt corn pollen on the Monarch butterfly (Lepidoptera: Danaidae)', <http://www.pme.iastate.edu/info/monarch.htm>

40 Shelton, A. and Roush, R. (1999) 'False reports and the ears of men', Nature Biotechnology, Vol. 17, p.832. 
41 Niller, E. (1999) 'GM corn poses little threat to monarch', Nature Biotechnology, Vol. 17, p.1154.

42 As another complexity for making comparisons, Bt maize does not always eliminate the need for insecticide usage; the evidence for such benefits is patchy $[43,44]$. Moreover, if the target pest is effectively controlled, then new opportunities may be opened to other pests, which in turn require more insecticides - as already happened when cultivating Bt cotton [45].

43 ENDS (1999) 'US studies call benefits of GM crops into question', ENDS Report 294, pp.10-11.

44 NCFAP (1999) Agricultural Biotechnology: Insect Control Benefits: Summary \& Conclusions, Washington, DC, National National Centre for Food \& Agriculture, www.bio.org/food\&ag/ncfap/ag_bio.htm

45 USDA/ERS (1999) Genetically Engineered Crops for Pest Management, USDA Economic Research Service, www.econ.ag.gov/whatsnew/issues/biotech.

46 EPA-OPPTS (1999) Letter to Bt Corn Registrants, http://www.epa.gov/pesticides/biopesticides/, December.

47 EEC (1990) Council Directive 90/220 on the Deliberate Release to the Environment of Genetically Modified Organisms, Official Journal of the European Communities, L 117, 8 May, pp.15-27.

48 CEC (1993) Towards Sustainable Development, 5th Environmental Action Program; also in Official Journal of the European Communities, C 138, 17 May, pp.5-98.

49 CEC (1993) Growth, Competitiveness, Employment: The Challenges and Ways Forward into the 21st Century, Bulletin of the European Communities, supplement 6/93.

50 Levidow, L., Carr, S., von Schomberg, R. and Wield, D. (1996) 'Regulating agricultural biotechnology in Europe: harmonization difficulties, opportunities, dilemmas', Science \& Public Policy, Vol. 23, No. 3, pp.135-57.

51 Levidow, L., Carr, S. and Wield, D. (1997) 'Environmental risk disharmonies of European biotechnology regulation', AgBiotech News \& Information, Vol. 9, No. 8, 179N-183N, http://agbio.cabweb.org/reviews/misc/levidow3.htm.

52 EC (1997) Commission Decision 97/98/EC of 23 January 1997 concerning the placing on the market of genetically modified maize, Official Journal of the European Communities, L 31, 1 February, pp.69-70. [Ciba-Geigy/Novartis dossier C/F/94/11-3]

53 INRA (1998) Organismes Génétiquement Modifiés à l'INRA: environnement, agriculture et alimentation, Paris, Institut National de la Recherche Agronomique.

54 SCP (1998) 'Opinion of the Scientific Committee on Plants Regarding Monsanto's MON10 Bt maize, 10 February. Full texts available at http://europa.eu.int/en/comm/dg24.

55 Roy, A. and Joly, P-B. (2000) 'France: broadening precautionary expertise?', Journal of Risk Research, Vol. 3, No. 3, forthcoming.

56 Ciba-Geigy (1994) Application for Placing on the Market a Genetically Modified Plant (Maize Protecting Itself against Corn Borers), Directive 90/220/EC', Part C, Notification $\mathrm{C} / \mathrm{F} / 94 / 11-03$.

57 Monsanto (1995) Application for placing on the market a genetically modified plant (InsectProtected maize line MON 810 and seeds of any progeny), according to Part C of Directive 90/220/EC, notification C/F/95/12-02, typescript; placed on UK public register, June 1996.

58 Ahl Goy, P. et al. (1995) 'Interactions of an insect-tolerant maize with organisms in the ecosystem', Key Biosafety Aspects of GMOs, pp.50-53. Berlin: Blackwell GmbH.

59 Pilcher, C.D., Obrycki, J., Rice, M.E. and Lewis, L.C. (1997) 'Preimaginal development, survival and field abundance of insect predators on transgenic Bt corn', Environmental Entomology, Vol. 26, pp.446-54.

60 Hoxter, K.A. and Lynn, S.P. (1992) 'Activated Btk HD-1 protein: a dietary toxicity study with green lacewing larvae', study number WL-92-155, an unpublished study conducted by Monsanto Company and Wildlife International Ltd. EPA MRID no.43468003. [cited in Monsanto, 1995]. 
61 Hilbeck, A. et al. (1998) 'Toxicity of Bt Cry1Ab toxin to the predator Chrysoperla carnea', Environmental Entomology, Vol. 27, No. 5, pp.1255-63.

62 Hilbeck, A. et al. (1998) 'Effects of transgenic Bt corn-fed prey on mortality and development time of immature Chrysoperla carnea', Environmental Entomology, Vol. 27, No. 2, pp.480-87.

63 In the Swiss study the controls had $37 \%$ high mortality rate, versus $62 \%$ for the Bt-fed insects. In another tri-trophic study, the control insects had a $68 \%$ mortality rate, versus $83 \%$ for the Bt-exposed insects; of the latter only $17 \%$ developed into adults

64 Riddick, E.W. and Barbosa, P. (1998) 'Impact of Cry3A-intoxicated Leptinotarsa decemlineata (Coleoptera: Chrysomelidae) and pollen on consumption, development, and fecundity of Coleomegilla maculata (Coleoptera: Coccinellidae)', Annals of the Entomological Society of America, Vol. 91, No. 3, pp.303-307

65 SCP (1998) Opinion of the Scientific Committee on Plants Regarding Pioneer's MON9 Bt, glyphosate-tolerant maize, 19 May.

66 Levidow, L., Carr, S. and Wield, D. (1999) 'Market-stage precautions: managing regulatory disharmonies for transgenic crops in Europe', AgBiotechNet, Vol. 1, pp.1-8, http://agbio.cabweb.org/reviews/April99/Html/Levidow.htm.

67 Levidow, L., Carr, S. and Wield, D. (2000) 'Genetically modified crops in the European Union: regulatory conflicts as precautionary opportunities', Journal of Risk Research, Vol. 3, No. 3, special issue on 'Precautionary Regulation: GM Crops in the EU'. 